\title{
Jurilinguistics: Ways Forward Beyond Law, Translation, and Discourse
}

\author{
Esther Monzó-Nebot ${ }^{1} \mathbb{D}$ - Javier Moreno-Rivero ${ }^{2} \mathbb{D}$
}

Published online: 30 May 2020

(c) The Author(s) 2020

\begin{abstract}
This is the guest editors' introductory paper to the special issue "Situating jurilinguistics across cultures using translation and discourse approaches." The introduction showcases the interdisciplinary vocation of jurilinguistics from its conception almost forty years ago. It is argued that jurilinguistics has achieved its current maturity by diversifying the disciplinary lenses of the originally contributing disciplines of legal translation and legal studies while keeping faithful to its original principles-facing practical problems with a rigorous outlook, venturing into any new domains that may prove enlightening, and combining professional and academic perspectives. The authors highlight how the series of conferences "Jurilinguistics: Interdisciplinary Approaches to the Study of Language and Law" have been instrumental in enhancing the scope of jurilinguistics. Finally, the articles gathered in this special issue are presented and their contributions in advancing the knowledge available for practitioners and scholars meeting at the interface between law and language are underscored.
\end{abstract}

Keywords Jurilinguistics · Interdisciplinarity $\cdot$ Translation studies $\cdot$ Legal translation $\cdot$ Legal discourse $\cdot$ Legal genres $\cdot$ Legal interpretation $\cdot$ Multilingualism

The term jurilinguistics was first used in an academic text by Jean-Claude Gémar [19] in a collective volume whose aim was to provide tools for the recently created profile of Canadian jurilinguists to face "the difficulties that jurists and translators must face when they are called upon to work together, to try and juxtapose two

Esther Monzó-Nebot monzo@uji.es

$\triangle$ Javier Moreno-Rivero jm2227@cam.ac.uk

1 Departament of Translation and Communication Studies, Universitat Jaume I, Av. Sos Baynat s/n, 12071 Castelló de la Plana, Spain

2 Theoretical and Applied Linguistics, Faculty of Modern and Medieval Languages and Linguistics, University of Cambridge, Sidgwick Ave, Cambridge CB3 9DA, UK 
experiences, to bring together two solitudes" [17]. The volume had the ambition to gather the views of the connected disciplines of translation studies and the law to allow both areas to cooperate in creating an interdisciplinary field that could cater to the emerging needs of legislative co-drafting in Canada's bicultural legal system [see [15, 18, 35, 49] ]. Explicitly born a chimerism between legal and translation studies, jurilinguistics called for an open mind to span disciplinary boundaries in the study of a complex domain, that emerging at the interface of law and language. Rather than placing a particular discipline at the service of another [contra [48], p. 54], jurilinguistics, as Gémar and Kasirer clarified years later [20], differs from "legal linguistics" or legilinguistics [see, e.g., [9, 38, 57] ] in that it encompasses an indefinite number of disciplines purposefully united to create knowledge on or to otherwise participate in the life of legal discourse (most particularly languages and texts), without limiting itself to any one setting (as opposed to, e.g., forensic linguistics).

From its conception, or even earlier [see [16] ], the chimeric interdiscipline of jurilinguistics immediately bloomed and it provided a successful framework for both scholars and 'practisearchers' [see [21] ] to reflect on issues concerning how the law operates through language and how language is conditioned by non-linguistic components and dynamics of legal systems. Manifold combinations of disciplines have collectively looked at the language of the law $[8,36]$; the law's discourse $[10,56]$ and meaning-making [13] processes; the translation of the law [22, 58]; the confluences between comparative law and translation [23]; the terminological complexities of translating legal systems [25, 52, 59]; issues of linguistic access for linguistic minorities [37]; the particularities of translation and interpreting for legal public services [60] —foregrounding settings, such as the courts of justice [28, 54], and context dependencies, such as the current migratory crisis [51]—; legislative drafting in multilingual contexts [47]; how to approach quality in legal translation [31]; the training needs of legal translators [43]; or the perspectives adopted in researching legal translation $[6,7]$, including efforts to decenter the scholarly reflection from subaltern and non-Western perspectives [2, 34, 39], among many other aspects of how the law shapes and is informed by its communication system. Those combinations have allowed scholars to determine the maturity of the interdisciplinary field of jurilinguistics [see [29] ], even when the term is not always used. Indeed, the bibliographic database e-lectra [42] includes only 221 texts containing the term "jurilinguistics" (including the original French jurilinguistique and the Spanish jurilingüistica), vis-à-vis 2171 texts including the expression "legal translation," 2033 using "legal language," or 910 texts using "language and law" or "law and language" (and equivalents in French and Spanish) to describe their objects.

However, the term shows clear advantages for the study of the targeted interdisciplinary field. Firstly, it allows us to show self-awareness as to the necessity of spanning boundaries when studying how law communicates. Secondly, it integrates a non-finite number of collaborating disciplines in a collective effort to create knowledge about the myriad ways in which law and language interact. And thirdly, its origins demand that both theoretical approaches and critical reflections are combined with the development of tools and guidelines to advance practice, as a requirement of an interdiscipline committed to increasing the knowledge on complex real-life 
issues. Indeed, this special issue of the International Journal for the Semiotics of Law is premised on the idea that only interdisciplinary efforts can ensure the cooperation and collaboration required to understand complex real-world phenomena.

Since 2016 this idea has been explored, discussed, and shared by a considerable number of scholars and practisearchers in the conference series "Jurilinguistics: Interdisciplinary Approaches to the Study of Language and Law,"1 a biannual event that has so far gathered 144 contributions from 23 different legal and linguistic systems, and that has kept its appeal to both academics and professionals in its third edition, currently in preparation. The founding idea of the conference was to enlarge jurilinguistics singling out the actual and potential contributions of sociological, political, and anthropological approaches to the existing body of textual and legal analyses advanced by the initial venture since the 1980s. The Jurilinguistics series has promoted interdisciplinary dialogue among researchers and professionals, including lawyers, judges, linguists, translators, interpreters, trainers, and educators, and also policymakers representing national and international organizations, private and public institutions. The variety of professional and academic traditions and epistemologies has provided a privileged lens to co-construct the relevant issues and the methods to approach them. Indeed, a growing number of researchers and practitioners have engaged in on-site meaning-making, contributing their different perspectives as the way to gain a closer understanding of the globalization of legal relationships. In the spirit of conviviality among disciplines and cultures, Jurilinguistics harbors a reconceptualized cosmopolitan ideal and has walked local and intradisciplinary experiences towards a common project that enshrines the diversity of the culturally rooted systems as the essential ingredient for mutually enriching cooperation.

The contributions gathered in this special issue are representative of major lines of interest in the field of jurilinguistics, as we have seen in the 317 proposals submitted as a response to the three past calls for papers for Jurilinguistics (with an increase of $36 \%$ between the first and second editions and a further $31 \%$ percent increase from Jurilinguistics II to Jurilinguistics III). The contributors who joined our project in this special issue are also representative of those who have participated in the Jurilinguistics conferences-engaged scholars who go to great lengths to overcome their own disciplinary limits, conceptually and personally, and successfully travel across boundaries. These authors are a selection of the many practitioners and academics that have honored us with their presence at the conferences, that have fully embraced the claim for intellectual flexibility as formulated by Gémar and Kasirer.

The first article in this special issue, "Comparative Law for Legal Translation: Through Multiple Perspectives to Multidimensional Knowledge," focuses on the interaction between comparative law and legal translation. Following on his previous work on how to abut the dialogue between these two fields [11, 12], Jan Engberg

\footnotetext{
1 The first two editions of Jurilinguistics were organized at the Universidad Pablo de Olavide (Seville, Spain), and the third edition is set to be held at the University of Cambridge, United Kingdom. See http:// www.jurilinguistica.com for further information.
} 
illustrates the different ways in which those two disciplines are instrumental to each other by arguing that both are forms of knowledge communication. A basic tenet of Engberg's approach is that knowledge is constructed by individuals, based on their experiences and perceptions, using texts as their working material. Those experiences and perceptions happen within a social context where the individual learns what the community endorses. Thus, the knowledge individually created is believed to be shared and social, and it circulates within a network of meaning-making associations. Within this framework, both disciplines aim at creating shareable knowledge on the law that can engender meaning, and both share the same challenge, as both comparative law and legal translation move across boundaries of social experiences and are aware of their need to communicate what cannot be presumed to be shared. Engberg's approach enlarges the fields of legal and translation studies by providing a framework from which the shared ingredients and the blank spaces revealed by comparisons can be assessed. In his proposal, the purposes and backgrounds of the individuals targeted by legal texts come to the fore, and so doing both translation and comparative law entails organizing differences and commonalities to (re)construct (more specifically, generate) relevant knowledge. Against this background, Engberg proposes to frame legal terms and legal translation as based on the knowledge of an epistemic community, located within a cultural system, and targeted to generate meaning interpersonally. Simultaneously considering those dimensions entails conceiving of translation as situated in and between-in particular situations that are prototypical of specific cultures but also between different individuals with different knowledge bases, expectations, and assumptions about other individuals' knowledge. Legal translation can be understood, explained, and advanced by locally and purposefully gathering, categorizing, selecting, and generating presumably shared knowledge across legal systems. Engberg's contribution thus wholly embraces our understanding of jurilinguistics as it augments cross-disciplinary dialogue and provides interdisciplinary tools to be used in advancing both academic knowledge and social practices.

A second contribution focuses on the areas of corpus linguistics and legal interpretation. In the last decades, corpus methods have been embraced by a number of disciplines. Particularly in translation studies, corpus methods have developed manifold applications [3, 32, 33], and they are gaining momentum in interpreting studies [50, 53], also in sign language interpreting [61]. Legal translation scholars have explored legal language (mostly, terminology and phraseology) with the assistance of corpus tools [5, 14, 24, 25, 41], and a large number of empirical studies attest to its efficiency in institutional legal settings [see [4, 40] ]. If we turn our attention to the field of legal studies, the applications of corpus methods for legal practice and adjudication have been known in the field for a long time [30] but its popularity had been marginal [27]. In more recent times, a rise in the application of computer science and artificial intelligence to the research conducted in legal studies can by identified. It is against this background that "Corpus Linguistics as a Method of Legal Interpretation: Some Progress, Some Questions," by Lawrence Solan, advocates for an enhanced use of corpora in legal scholarship and interpretation. The author explores the uses of corpora in scrutinizing the legal meaning attributed to specific words with a view to underscoring the risks and benefits of corpus approaches in 
the field of legal interpretation. Based on the principle applied in the interpretation of statutes by US courts that terms are to be given its "ordinary" meaning unless explicitly defined, Solan illustrates how meaning is derived from context and how US practices have deprived terms from the context where they occur, thereby opening windows for interpretation biases and ideological interference. The author illustrates his case with polysemic words such as use, toys, or destroy, and he aptly shows how reliable and systematic corpus methods can narrow down precedential meanings by tracing contextualized examples in previous cases, advocating for both close and distant reading [see [45] ] of precedents. Solan concludes by calling for interdisciplinary efforts between law and linguistic professionals to ensure a systematic and rigorous application of corpus linguistics by the courts in interpreting precedents.

Further focusing on the US principles of legal interpreting, in "Translation Approaches in Constitutional Hermeneutics", Hans Lind, Christina Mulligan, Michael Douma, and Brian Quinn propose to approach legal translations as sources for legal interpretation. Based on the idea that translations are a form of holistic analysis, interpretation, and reconstruction, they focus on how founding-era translations of the US Constitution can contribute to elucidating the meaning of controversial terms and passages in originalist interpretation, from a contemporaneous multilingual commentary of the founding text. The authors understand translation as an activity charged with exegetical value, which makes all legal translators the result of a learned debate on the original texts. In advocating that translation involves an informed interpretation of the original text, the authors incite a post-structuralist discussion of legal translation within the field of legal studies, in line with the current approaches in translation and interpreting studies [see [1] ]. More specifically, the authors examine the German and Dutch translations of the US Constitution that were commissioned for the German- and Dutch-speaking populations of Pennsylvania and New York before the ratification of the US Constitution, and establish a dialogue across linguistic versions. Resorting to lexical and legal sources, their analysis of the selected founding-era translations clarifies controversial meanings from a contemporaneous perspective. The authors' contribution advances the field of jurilinguistics enhancing the dialogue between legal and translation studies and providing new tools for the practice of constitutional interpretation.

A different multidisciplinary approach is taken by Juan Jiménez-Salcedo in "Le débat autour du bilinguisme des juges à la Cour suprême du Canada : analyse de la doctrine et des débats parlementaires" ("The discussion regarding the bilingualism of Canada's Supreme Court of Justice: An analysis of the doctrine and the parliamentary debates'). Based on the apparent disfunction created by the fact that supreme justices are not required to master the French language and yet decide on the constitutional compliance of cases developed in both English and French, read precedents written in French, and interpret legislation published in English and French, the author reviews how this issue has been framed in judicial decisions and political debates, resulting in a number of more or less ambiguous and more or less successful bills. By aptly reviewing positions and developments, Jiménez-Salcedo identifies arguments regarding the right to be understood by a judge as a linguistic right, the consideration of bilingualism as a legal competence, and the definition of the degree of bilingualism necessary to fulfill the obligations of a judge of the 
Supreme Court as discussed in contemporary Canada. In his analysis, the author makes visible the inextricable link between the political and the legal systems in providing recognition to the different societal sectors and fulfilling the rights of subaltern communities [see [26] ]. In line with his previous work in the area [see [44] ], the author highlights the role of translation and interpreting in the policies that can ensure social cooperation across differences. More specifically, he points out how translation and interpreting may be instrumental in approaching the positions of those regarding the bilingualism of appointed judges as an essential element for the protection of the rights of the French-speaking population and those considering that the demands of linguistic competence hinder the access of eminent judges to Canada's Supreme Court. Jiménez-Salcedo's contribution thus opens a window onto further possibilities for interdisciplinary collaboration in real-life situations.

Elyse Methven's contribution, "Commodifying Justice: Discursive Strategies Used in the Legitimation of Infringement Notices for Minor Offences," takes a discursive approach to the legal and political issues surrounding the emergence of a new genre, penalty notices. Penalty notices are administrative (or civil) measures that law-enforcement agents are allowed to apply to monitor and enforce compliance with the law without a court's supervision. Methven stresses the surprising popularity and growth of penalty notices, especially considering that they reduce the protection given by the courts in criminal proceedings. To examine how penalty notices have achieved such success when introducing major disturbances regarding basic legal principles, the author examines the discourse on this genre in a corpus of parliamentary debates, media releases, and interviews with law-enforcement agents conducted by herself. By identifying salient ideological keywords, common topics and frames, the author establishes the success of a neoliberal discourse framing the controlling function of the courts as time-consuming and ineffective, foregrounding the costs of due process against the expedite nature of administrative penalties and the urgency of police surveillance, trivializing the protections warranted by the courts, and silencing the wearying of a concept of law as justice. Contributing to the current debate in the field of legal studies about how neoliberalism has taken human rights hostage [see [46] ], Methven clearly demonstrates how discourse studies (more specifically, critical discourse analysis) can contribute to legal studies in issues far beyond communication, attached to the very essence of and expectations on the Law.

Finally, in "Communicating Dissent in Judicial Opinions: A Comparative, GenreBased Analysis," Stanisław Goźdź-Roszkowski develops a comparative linguistic analysis of the genre 'separate opinions' (also known as votum separatum) in the Polish and US legal systems, thereby comparing a civil-law and a common-law system. The author first establishes a systemic preference for absolute agreement among judges deciding over a case. This preference is grounded on the legal and social impact of presenting findings as contestable, and a general aversion against showing the agency of the judges in adjudication. Showing individual dissent is seen as departing from the impersonal style of judicial decisions in both legal systems, even when common-law judgements are prone to show the personal voice of judges. Even though dissent is increasingly accepted, a lack of guidelines on how to formulate separate opinions provides considerable leeway for judges to express and justify 
their dissent. Based on a comparable corpus, the author analyzes how justifications in general are phrased in the judgements, identifies frequent expressions in both languages, and studies the identified linguistic forms in their contexts. The results of the analysis show a preference for non-creative and highly formulaic expressions to indicate disagreement with the majority vote. Against the background of a general lack of knowledge on this genre, the conclusions lead the author to establish the entitativity of both votum separatum and the actual justification of the dissent as two different genres. This contribution represents the legal linguistic tradition in the study of legal genres, where the links between the legal normative and non-normative traditions and the linguistic forms and their recurrence and prototypicality are revealed, contributing knowledge on how both the legal and the linguistic systems operate. Adopting a comparative perspective across legal systems, it provides insights that can be applied in the translation of the genres under scrutiny, fulfilling Trosborg's claim to create knowledge about legal discourse across languages and cultures [55].

The editors of this volume consciously chose jurilinguistics as a conceptual tool to garner views on the confluences between language and law because, as seen in the contributions included in this special issue, it encapsulates and extends the approaches from a number of disciplines by continuing to allow the questions that those disciplines pose to be scrutinized, and at the same time extending them by enabling more comprehensive and pertinent issues to be framed. Collectively, the papers gathered in this special issue establish a dialogue with the tradition of jurilinguistics and, at the same time, bring the discussion forward by making significant contributions to the interdisciplinary discussion that characterizes the field. The bridges built between (intra)disciplinary perspectives span translation studies, comparative law, linguistics, discourse studies, political science, the philosophy of law, sociolinguistics, hermeneutics, and communication studies, creating new knowledge on complex and socially relevant phenomena that can be harnessed by practitioners. By developing product- (Methven, Goźdź-Roszkowski) and process- (Engberg, Solan, Lind et al., Jiménez-Salcedo) oriented studies, the authors in this special issue of the International Journal for the Semiotics of Law have brought forward the epistemological configuration of jurilinguistics, a revamped view that nonetheless honors the essential principles formulated almost forty years ago.

Open Access This article is licensed under a Creative Commons Attribution 4.0 International License, which permits use, sharing, adaptation, distribution and reproduction in any medium or format, as long as you give appropriate credit to the original author(s) and the source, provide a link to the Creative Commons licence, and indicate if changes were made. The images or other third party material in this article are included in the article's Creative Commons licence, unless indicated otherwise in a credit line to the material. If material is not included in the article's Creative Commons licence and your intended use is not permitted by statutory regulation or exceeds the permitted use, you will need to obtain permission directly from the copyright holder. To view a copy of this licence, visit http://creativecommons.org/licen ses/by/4.0/. 


\section{References}

1. Angelelli, Claudia V., and Brian James Baer. 2016. Exploring Translation and Interpreting. In Researching Translation and Interpreting, ed. Claudia V. Angelelli and Brian James Baer, 5-13. London and New York: Routledge.

2. Angelo, Tony, Janet Holmes, and Māmari Stephens (eds). 2011. Law and Language in the South Pacific: Comparative Studies. Special issue of Victoria University of Wellington Law Review 42 (2).

3. Baker, Mona. 1993. Corpus Linguistics and Translation Studies-Implications and Applications. In Text and Technology. In Honour of John Sinclair, ed. Mona Baker, Gill Francis, and Elena TogniniBonelli, 233-250. Amsterdam: John Benjamins.

4. Biel, Łucja. 2014. Lost in the Eurofog. The Textual Fit of Translated Law. Frankfurt am Main: Peter Lang.

5. Biel, Łucja. 2014. The Textual Fit of Translated EU law: A Corpus-Based Study of Deontic Modality. The Translator 20: 1-24. https://doi.org/10.1080/13556509.2014.909675.

6. Biel, Łucja, and Jan Engberg (eds). 2013. Research Models and Methods in Legal Translation. Special issue of Linguistica Antverpiensia 12.

7. Biel, Łucja, Jan Engberg, Rosario Martín Ruano, and Vilelmini Sosoni (eds). 2019. Research Methods in Legal Translation and Interpreting. Crossing Methodological Boundaries. London: Routledge.

8. Campos Pardillos, Miguel Ángel, and Shaeda Isani (eds). 2015. Language and the Law. Special issue of Alicante Journal of English Studies 28.

9. Cornu, Gérard. 2000. Linguistique juridique. Paris: Montchrestien.

10. Danet, Brenda (ed). 1984. Studies of Legal Discourse. Special issue of Text 4 (1-3).

11. Engberg, Jan. 2016. Conceptualising Corporate Criminal Liability: Legal Linguistics and the Combination of Descriptive Lenses. In Constructing Legal Discourses and Social Practices: Issues and Perspectives, ed. Girolamo Tessuto, Vijay K. Bhatia, Giuliana Garzone, Rita Salvi, and Christopher Williams, 28-56. Newcastle upon Tyne: Cambridge Scholars.

12. Engberg, Jan. 2017. Developing an Integrative Approach for Accessing Comparative Legal Knowledge for Translation. Revista de Llengua i Dret 68: 5-18. https://doi.org/10.2436/rld.i68.2017.3014.

13. Engberg, Jan, and Kirsten Wølch Rasmussen (eds). 2010. Cognition, Meaning Making, and Legal Communication. Special issue of The International Journal for the Semiotics of Law 23 (4).

14. Fanego, Teresa, and Paula Rodríguez-Puente (eds). 2019. Corpus-Based Research on Variation in English Legal Discourse. Amsterdam: John Benjamins.

15. Ferran Larraz, Elena. 2014. Las fases del proceso traductor. La traducción de las funciones universales Common law vs. Civil law mediante la traducción paralela. El trust, un estudio de caso [The phases of the translation process. Translation of the universal functions 'Common law' vs. 'Civil law' through parallel translation. The trust, a case study]. Revista de Llengua i Dret 61: 1-25. https://doi. org/10.2436/20.8030.02.51.

16. Gémar, Jean-Claude (ed). 1979. La traduction juridique. Special issue of Meta. Journal des traducteus 24 (1).

17. Gémar, Jean-Claude. 1982. Avant-propos/Foreword. In Langage du Droit et Traduction: Essai de Jurilinguistique. The Language of the Law and Translation, ed. Jean Claude Gémar. Essays on Jurilinguistics. Montreal: Linguatech.

18. Gémar, Jean-Claude. 2013. Translating vs Co-Drafting Law in Multilingual Countries: Beyond the Canadian Odyssey. In Legal Translation in Context. Professional Issues and Prospects, ed. Anabel Borja and Fernando Prieto, 27-51. New Trends in Translation Studies. Bern: Peter Lang.

19. Gémar, Jean-Claude (ed). 1982. Langage du droit et Traduction: Essais de Jurilinguistique. The Language of the Law and Translation. Essays on Jurilinguistics. Montreal: Linguatech.

20. Gémar, Jean-Claude, and Nicholas Kasirer. 2005. Foreword. In Jurilinguistique: Entre Langues et droits-Jurilinguistics: Between Law and Language, ed. Jean-Claude Gémar and Nicholas Kasirer. Bruylant: Thémis.

21. Gile, Daniel. 2018. Research into Translation as a Specialism: An Analysis and Recommendations. The Journal of Specialised Translation 30: 23-39.

22. Glanert, Simone (ed). 2014. Law in Translation. Special issue of The Translator 20 (3).

23. Glanert, Simone (ed). 2014. Comparative Law_Engaging with Translation. Oxon: Routledge.

24. Goźdź-Roszkowski, Stanisław, and Gianluca Pontrandolfo (eds). 2017. Phraseology in Legal and Institutional Settings. A Corpus-Based Interdisciplinary Perspective. London: Routledge. 
25. Goźdź-Roszkowski, Stanisław, and Iwona Witczak-Plisiecka (eds). 2011. Legal Terminology: Approaches and Applications. Special issue of Research in Language 9 (1).

26. Honneth, Axel. 1995. The Moral Grammar of Social Conflict. Trans. Joel Anderson. Cambridge: Polity Press.

27. Hutton, Christopher. 2009. Language, Meaning, and the Law. Edinburgh: Edinburgh University Press.

28. Ilg, Gérard (ed). 1989. Court Interpreting. Special issue of Parallèles 11.

29. Jiménez-Salcedo, Juan, and Javier Moreno-Rivero. 2017. On Jurilinguistics: The Principles and Applications of Research on Language and Law. Revista de Llengua i Dret 68: 1-4. https://doi.org/10.2436/ rld.i68.2017.3064.

30. Kaplan, Jeffrey, Georgia Green, Clark Cunningham, and Judith Levi. 1995. Bringing Linguistics Into Judicial Decision-Making: Semantic Analysis Submitted to the US Supreme Court. Forensic Linguistics: The International Journal of Speech, Language and the Law 1: 81-98.

31. Kockaert, Hendrik J., and Nadia Rahab (eds). 2017. Quality in Legal Translation. Special issue of The Journal of Specialised Translation 27.

32. Kruger, Alet, Kim Wallmach, and Jeremy Munday (eds). 2011. Corpus-Based Translation Studies: Research and Applications. London: Continuum.

33. Laviosa, Sara. 1998. The Corpus-Based Approach: A New Paradigm in Translation Studies. Meta: Journal des traducteurs 43 (4): 474-479. https://doi.org/10.7202/003424ar.

34. Lenoble-Pinson, Michèle, and Anne Wagner (eds). 2006. The Feminine in Legal Discourse. Special issue of The International Journal for the Semiotics of Law 19 (1).

35. Levert, Lionel A. 2015. La Jurilinguistique: Un Appui Indispensable à la Corédaction. International Journal for the Semiotics of Law 28 (1): 53-72.

36. Linderfalk, Ulf (ed). 2017. Language and International Law. Special issue of Nordic Journal of International Law 86 (2).

37. Lucas, Ceil (ed). 2003. Language and the Law in Deaf Communities. Washington: Gallaudet University Press.

38. Mattila, Heikki. 2006. Comparative Legal Linguistics. Aldershot: Ashgate.

39. Matulewska, Aleksandra (ed). 2019. Legal and LSP Linguistics and Translation: Asian Languages' Perspectives. Special issue of International Journal for the Semiotics of Law 32 (1).

40. McAuliffe, Karen, and Aleksandar Trklja. 2018. Superdiversity and the Relationship Between Law, Language and Translation in a Supranational Legal Order. In The Routledge Handbook of Language and Superdiversity, ed. Angela Creese and Adrian Blackledge, 426-441. Abingdon-on-Thames: Routledge.

41. Monzó-Nebot, Esther. 2008. Corpus-based Activities in Legal Translator Training. The Interpreter and Translator Trainer 2 (2): 221-252. https://doi.org/10.1080/1750399X.2008.10798775.

42. Monzó-Nebot, Esther. 2010. E-lectra. A Bibliography for the Study and Practice of Legal Court and Official Translation and Interpreting. Meta: Journal des traducteurs 55 (2): 355-373. https://doi. org/10.7202/044245ar.

43. Monzó-Nebot Esther (ed). 2015. Training Legal Interpreters and Translators. Special issue of The Interpreter and Translator Trainer 9 (2).

44. Monzó-Nebot, Esther, and Juan Jiménez-Salcedo (eds). 2018. Translating and Interpreting Justice in a Postmonolingual Age. Delaware: Vernon Press.

45. Moretti, Franco. 2013. Distant Reading. London: Verso.

46. Moyn, Samuel. 2018. Not Enough: Human Rights in an Unequal World. Cambridge: Harvard University Press.

47. Pennisi, Giulia Adriana (ed). 2014. Legislative Drafting and Linguistics-Strategies to Communicate the Law. Special issue of The Theory and Practice of Legislation 2 (2).

48. Poirier, Lise. 2009. Whose Law is it? A Jurilinguistic View from the Trenches. Paper presented at the CALC Conference, Hong Kong, 1-5 April.

49. Preite, Chiara. 2013. Des années 1970 au nouveau millénaire: essor de la jurilinguistique ou linguistique juridique. Parallèles 25: 42-50.

50. Russo, Mariachiara, Claudio Bendazzoli, and Bart Defrancq (eds). 2018. Making Way in Corpus-based Interpreting Studies. New Frontiers in Translation Studies. Singapore: Springer.

51. Schuster, Michal, and Lluís Baixauli-Olmos (eds). 2018. A Question of Communication: The Role of Public Service Interpreting in the Migrant Crisis. Special issue of The European Legacy 23 (7-8).

52. Schwab, Wallace (ed). 2002. Traduction et Terminologie Juridiques. Special issue of Meta Journal des traducteurs 47 (2). 
53. Shlesinger, Miriam. 1998. Corpus-Based Interpreting Studies as an Offshoot of Corpus-Based Translation Studies. Meta: Journal des traducteurs 43 (4): 486-493. https://doi.org/10.7202/004136ar.

54. Shlesinger, Miriam, and Franz Pöchhacker (eds). 2008. Doing Justice to Court Interpreting. Special issue of Interpreting 10 (1).

55. Trosborg, Anna. 1995. Introduction. Journal of Pragmatics 23: 1-5.

56. Trosborg, Anna (ed). 1995. Legal Discourse. Special issue of Journal of Pragmatics 23.

57. Vogel, Friedemann. 2019. Legal Linguistics Beyond Borders: Language and Law in a World of Media, Globalisation and Social Conflicts. Berlin: Duncker \& Humblot.

58. Wagner, Anne, and Jean Claude Gémar (ed). 2013. The Process of Translabiliting: Translating and Transferring Law, its Concepts, Notions and Language. Special issue of The International Journal for the Semiotics of Law 26 (4).

59. Wagner, Anne, and Jean-Claude Gémar (eds). 2015. Legal Translation and Jurilinguistics: Globalizing Disciplines. Retrospects and Prospects. Special issue of The International Journal for the Semiotics of Law 28.

60. Wallace, Melissa, and Esther Monzó-Nebot (eds). 2019. Legal Translation and Interpreting in Public Services. Special issue of Revista de Llengua i Dret 71.

61. Wehrmeyer, Ella. 2019. A Corpus for Signed Language Interpreting Research. Interpreting 21 (1): 62-90. https://doi.org/10.1075/intp.00020.weh.

Publisher's Note Springer Nature remains neutral with regard to jurisdictional claims in published maps and institutional affiliations. 